Jrnal Ilmiah Ibnu Sina, 6(1), Maret 2021, 69-78

p-ISSN: 2502-647X; e-ISSN: 2503-1902

\title{
UJI TOKSISITAS DENGAN METODE BSLT PADA NANOPARTIKEL KOMBINASI OBAT CISPLATIN, BOVINE SERUM ALBUMIN DAN ASAM FOLAT
}

\author{
Ersalina Nidianti*, Ary Andini \\ Prodi Analis Kesehatan, Fakultas Kesehatan, Universitas Nahdlatul Ulama \\ Surabaya \\ Email*: ersalinanidianti@unusa.ac.id
}

Artikel diterima: 30 September2020; Disetujui: 22 Maret 2021

DOI: https://doi.org/10.36387/jiis.v6i1.609

\begin{abstract}
ABSTRAK
Kanker adalah penyakit tidak menular yang menyebabkan mordibitas dan mortalitas di seluruh wilayah dunia. Pengobatan kanker menjadi hal penting dalam mengurangi tingginya jumlah angka kematian (mortalitas) karena penderita penyakit kanker. Salah satu pengobatan kanker adalah dengan menggunakan obat kemoterapi cisplatin. Akan tetapi obat cisplatin memiliki efek samping yaitu nefrotoksisitas, ototoksisitas,neurotoksisitas,hemotologistoksisitas,kardiotoksisitas, dan hepatotoksisitas. Oleh karena itu kombinasi cisplatin dalam nanopartikel albumin dan modifikasi ikatan menggunakan asam folat sebagai solusi alternatif meminimalisir efek toksik yang dihasilkan. Tujuan penelitian untuk mengetahui efek toksisitas formulasi obat cisplatin dengan kombinasi nanopartikel bovine serum albumin (BSA) dan asam folat melalui metode Brine Shrimp Lethality Test (BSLT). Metode penelitian yang dilakukan yaitu sintesis nanopartikel BSA (NPBSA), Sintesis NP-BSA dengan Obat Cisplatin (CP-NP-BSA), Sintesis Asam Folat dengan Kombinasi CP-NP-BSA (As-CP-NP-BSA). Kemudian dilakukan uji toksisitas dengan metode BSLT untuk mengetahui kadar toksisitas nanopartikel BSA serta pengaruh penambahan asam folat dalam obat cisplatin dalam nanopartikel. Hasil diperoleh bahwa absorbansi dari Spektrofotometer UV-Vis panjang gelombang $358 \mathrm{~nm}$ As-CP-NP-BSA sebesar 0,86. Kadar toksisitas pada NP-BSA dengan nilai $\mathrm{LC}_{50}$ 69,23 ppm sedangkan kadar toksisitas As-CP-NP-BSA $\mathrm{LC}_{50} 56,56 \mathrm{ppm}$. Nanopartikel yang terdiri dari kombinasi bovine serum albumin, cisplatin dan asam folat dapat dijadikan sebagai kandidat obat antikanker.
\end{abstract}

Kata kunci: Cisplatin, Antikanker, Nanopartikel, Toksisitas

\section{ABSTRACT}

Cancer is a non-communicable disease that causes morbidity and mortality in all regions of the world. Cancer treatment is important in reducing the high number of deaths (mortality) due to cancer sufferers. One of the cancer treatments is using chemotherapy drug cisplatin. However, cisplatin drug has side effects, namely nephrotoxicity, ototoxicity, neurotoxicity, hemotoxicity, cardiotoxicity, and hepatotoxicity. Therefore, the combination of cisplatin in albumin nanoparticles and modification of the bond using folic acid as an alternative solution minimizes 
Jrnal Ilmiah Ibnu Sina, 6(1), Maret 2021, 69-78

p-ISSN: 2502-647X; e-ISSN: 2503-1902

the resulting toxic effects. This study aimed to determine the toxicity effect of the cisplatin drug formulation with a combination of bovine serum albumin (BSA) nanoparticles and folic acid through the Brine Shrimp Lethality Test (BSLT) method. The research methods used were BSA nanoparticle synthesis (NP-BSA), NP-BSA Synthesis with Cisplatin Drug (CP-NP-BSA), Folic Acid Synthesis with $C P-N P-B S A$ Combination (As-CP-NP-BSA). Then, a toxicity test was carried out using the BSLT method to determine the toxicity level of BSA nanoparticles and the effect of adding folic acid in the cisplatin drug in the nanoparticles. The results showed that the absorbance of the $358 \mathrm{~nm}$ As-CP-NP-BSA UV-Vis spectrophotometer was 0.86 . The toxicity level of the NP-BSA with the LC50 value was $69.23 \mathrm{ppm}$ while the As-CP-NP-BSA LC50 toxicity level was $56.56 \mathrm{ppm}$. Nanoparticles consisting of a combination of bovine serum albumin, cisplatin and folic acid can be used as candidates for anticancer drugs.

Keywords: Cisplatin, Anticancer, Nanoparticles, Toxicity

\section{PENDAHULUAN}

Kanker merupakan penyakit tidak menular yang menyebabkan morbidibitas dan mortalitas di seluruh wilayah dunia. Data dari laporan Global Burder Cancer (Globocan) pada tahun 2018 menunjukkan bahwa ada 18,1 juta kasus baru kanker dengan 9,6 juta kasus kematian disebabkan kanker (Bray et al. 2018). Berdasarkan data Riskesdas pada tahun 2018 prevalensi kanker di Indonesia menunjukkan adanya peningkatan dari 1,4 per 1.000 penduduk ditahun 2013 menjadi 1,79 per 1.000 penduduk ditahun 2018.

Penyebab terjadinya kanker karena adanya perubahan struktur dan fungsi secara genetik. Penyakit kanker dikarenakan kondisi sel mengalami pertumbuhan yang tidak normal dan tidak terkendali. Penyakit ini ditandai sel-sel dalam tubuh manusia terus berkembang biak dan tidak mampu dikendalikan atau dihentikan sehingga terbentuk tumor atau sel-sel ganas yang berpotensial menjadi metastasis (Rahmani et al. 2014). Pengobatan kanker dilakukan secara intensif seperti: pembedahan, kemoterapi, radioterapi. Pengobatan kanker secara kemoterapi merupakan salah satu pengobatan yang digunakan untuk menghancurkan sel-sel kanker dengan menghambat pertumbuhan dan perkembangan sel kanker. Kemoterapi melibatkan penggunaan obat dengan berat molekul yang rendah untuk menghancurkan sel tumor secara selektif (Mutiah, Suryadinata, and 
Jrnal Ilmiah Ibnu Sina, 6(1), Maret 2021, 69-78

p-ISSN: 2502-647X; e-ISSN: 2503-1902

Nurani 2018).

Salah satu obat kemoterapi yang digunakan untuk pengobatan kanker adalah cisplatin. Cisplatin dapat digunakan untuk pengobatan berbagai jenis kanker pada manusia seperti kanker ovarium, paru-paru, testis, kandung kemih, payudara, otak dll. Cisplatin diberikan melalui intervena sebagai infus jangka pendek dalam larutan saline untuk pengobatan kanker ganas. Pemberian cisplatin pada pengobatan kanker dapat memicu proses pembelahan sel yang tidak normal \& berpotensi menyerang sel yang berdekatan (Aldossary 2019). Penggunaan secara klinis cisplatin dibatasi karena adanya efek samping yang bersifat toksik yang bergantung pada dosis. Toksisitas cisplatin yaitu nefrotoksisitas,ototoksisitas,neurotoks isitas, hemotologis toksisitas, kardiotoksisitas, dan hepatotoksisitas. Karena efek samping yang dihasilkan tersebut dibuatlah obat berbasis nanopartikel (Qi et al. 2019).

Obat dengan sistem penghantar obat (drug delivery) berbasis nano telah dikaji dan diteliti untuk meminimalkan efek samping dari obat cisplatin, mengurangi toksisitas obat serta mampu meningkatkan efisiensi antineoplastik dan meningkatkan kemanjuran obat. (Alam et al. 2015). Penelitian yang telah dilakukan oleh (Kettering et al. 2009) penggunaan cisplatin dengan kombinasi nanopartikel magnetik menunjukkan aktivitas kemoterapi akan tetapi menghasilkan efek samping tubuh terasa panas. Oleh karena itu, dalam penelitian ini digunakan nanopartikel dari bahan polimer organik seperti albumin, yang diperoleh dari bovine serum albumin (BSA) dikombinasi dengan obat cisplatin dan modifikasi ikatan menggunakan asam folat untuk meminimalisir toksisitas obat.

Penelitian ini bertujuan untuk mengetahui efek toksisitas formulasi obat cisplatin dengan kombinasi nanopartikel bovine serum albumin (BSA) dan asam folat melalui metode Brine Shrimp Lethality Test (BSLT).

\section{METODE PENELITIAN}

\section{Alat dan Bahan}

Alat-alat yang digunakan dalam penelitian yaitu: erlenmeyer $600 \mathrm{ml}$, neraca analitik, magnetik stirer, gelas ukur $100 \mathrm{ml}$, pipet tetes, pipet volume, hot plate, sentrifuse, Spektrofotometer 
Jrnal Ilmiah Ibnu Sina, 6(1), Maret 2021, 69-78

p-ISSN: 2502-647X; e-ISSN: 2503-1902

UV-Vis.

Bahan-bahan yang digunakan dalam penelitian: Etanol $95 \%$, Cisplatin, larutan Bovine Serum Albumin (BSA), $\mathrm{NaOH}, \quad$ larutan Phosphat Buffer Saline (PBS), Gluteraldehid, Asam folat, aquades, aquabidest, dan pelarut kimia lainnya.

Sintesis Nanopartikel Bovine Serum Albumin (NP-BSA)

Sintesis nanopartikel bovine serum albumin (BSA) dilakukan dengan menggunakan teknik desolvasi. Larutan BSA (4\% w/v) dengan pH 7 ditambahkan etanol $(0,5$ $\mathrm{ml} /$ menit dengan interval 2 menit) dilakukan pengadukan menggunakan magnetik stirrer $600 \mathrm{rpm}$. Kemudian ditambahkan $8 \%$ gluteraldehid $(1,7$ $\mu \mathrm{l} / \mathrm{mg}$ BSA) didiamkan selama 6 jam pada temperatur ruang dengan pengadukan magnetik stirer (600 rpm) hingga terbentuk larutan keruh. Nanopartikel yang dihasilkan dimurnikan dengan menggunakan sentrifugasi, kemudian dicuci dengan menggunakan Phosphat Buffer Saline (PBS) steril. Kemudian nanopartikel yang terbentuk disimpan dalam desikator (Alam et al. 2015).
Sintesis Nanopartikel Bovine Serum Albumin dengan Obat Cisplatin (CP-NP-BSA)

Obat cisplatin diinkubasi selama 24 jam kemudian ditambahkan larutan BSA (4\% w/v) pada suhu $37{ }^{\circ} \mathrm{C}$ dan dilakukan pengadukan stirer kemudian ditambahkan $\mathrm{NaOH}$ 0,1 N (Alam et al. 2015).

Sintesis Asam Folat dengan Kombinasi Nanopartikel Bovine Serum Albumin dengan Obat Cisplatin (As-CP-NP-BSA)

Nanopartikel BSA (NP-BSA) dan cisplatin nanopartikel BSA (CPNP-BSA) dimodifikasi dengan asam folat. Asam folat ditambahkan dengan PBS \& Sorbitol dengan perbandingan (1:2:2) kemudian distirer 15 menit pada temperatur ruang. Jumlah NPBSA dan CP-NP-BSA yang ditambahkan sebanyak $20 \mathrm{mg} / \mathrm{ml}$ dan distirer dengan magnetik stirer selama 4-5 jam. Hasil disentrifugasi dan siap untuk analisis (Alam et al. 2015).

\section{Uji Toksisitas Metode BSLT}

Telur Artemia Salina (A.salina) $0.5 \mathrm{~g}$ ditetaskan dalam media air laut (35\% kadar garam), bersirkulasi udara yang baik dan pencahayaan yang terang dan suhu $24-26^{\circ} \mathrm{C}$. Setelah $12-$ 
Jrnal Ilmiah Ibnu Sina, 6(1), Maret 2021, 69-78

p-ISSN: 2502-647X; e-ISSN: 2503-1902

48 jam telur menetas, salinitas pembuatan nanopartikel berdasarkan dikurangi hingga 5\% untuk uji BSLT, perbedaan kelarutan antara tidak boleh umur 7 hari dan tidak boleh kurang dari 3 hari. Untuk senyawa murni dibuat konsentrasi 1 , 10 dan 100 ppm.

Disiapkan beberapa vial (tabung reaksi) yang masing-masing diisi dengan $5 \mathrm{ml}$ air laut dan $5 \mathrm{ml}$ larutan sampel dengan konsentrasi $(1,10,20$, $30,40,50,60,70,80 \mathrm{ppm})$ serta 10 ekor A. salina. Lakukan hal yang sama untuk kontrol dengan pelarut (etanol atau DMSO). Waktu kontak dilihat 1 jam hingga 6 jam. Replikasi dilakukan sebanyak 3X, hitung nilai $\mathrm{LC}_{50}$ dengan SPSS. Karena A.salina langsung kontak dengan sampel, maka dapat diketahui jumlah A.salina yang hidup dan jumlah yang mati, berdasarkan rumus

Evaluasi:

$\%$ Kematian $=\frac{\text { Total kematian A.salina } \text { - } \text { Kontrol }}{\text { Total larva hewan coba }} \times 100$ (Meyer et al. 1982).

\section{HASIL DAN PEMBAHASAN}

Sintesis Nanopartikel Bovine Serum Albumin (NP-BSA)

Preparasi nanopartikel bovine serum albumin (BSA) dilakukan dengan metode desolvasi (yaitu teknik desolvating agent dengan pelarut air yang bercampur BSA). Kelarutan BSA dalam air tinggi bila ditambahkan desolvating agent/ pelarut pendesolvasi seperti (etanol, aseton, dan DMSO) sehingga membentuk agregrat dari BSA dan ditambahkan crosslinker yang didasarkan pada karakteristik fisiko kimia (Ambarwati 2019). Sintesis dilakukan dengan mencampur larutan BSA, etanol 96\% (sebagai desolvating agent) dan gluteraldehid $8 \%$ (sebagai crosslinker) distirerr 600 rpm selama 6 jam. Kemudian nanopartikel dicuci dengan PBS $\mathrm{pH} \quad 7.4$ steril dan disentrifugasi $2000 \mathrm{rpm}$ selama 5 menit. Terbentuk dua lapisan yaitu filtrat dan endapan kemudian dipisahkan dan disimpan dalam desikator (Usreg, Husein, and Fahmi, Ph.D 2019), (Alam et al. 2015). Parameter optimasi pada penelitian ini bergantung pada jenis desolvating agent, jumlah pelarut pendesolvasi, jumlah larutan BSA yang digunakan, jumlah desolvating agent, lama pengadukkan dan $\mathrm{pH}$ pelarut (Ambarwati 2019). 
Jrnal Ilmiah Ibnu Sina, 6(1), Maret 2021, 69-78

p-ISSN: 2502-647X; e-ISSN: 2503-1902

Sintesis Nanopartikel Bovine Serum

Albumin dengan Obat Cisplatin (CP-NP-BSA)

Cisplatin sebagai agen kemoterapi yang dianggap penting dalam pengobatan kanker. Pemberian cisplatin dalam waktu lama dapat mempengaruhi efektivitas organ dan menghasilkan efek samping sehingga perlu dilakukan kombinasi cisplatin untuk mengurangi toksisitas obat tersebut salah satunya dalam bentuk nanopartikel (Syame et al. 2018). Sintesis nanopartikel BSA dengan obat cisplatin dilakukan dengan penambahan NP-BSA yang terbentuk kemudian ditambahkan $\mathrm{NaOH} 0,1 \mathrm{~N}$ dan dilakukan pengadukan stirer 600 rpm (Alam et al. 2015).

\section{Sintesis Asam Folat dengan Kombinasi Nanopartikel Bovine Serum Albumin dengan Obat Cisplatin (As-CP-NP-BSA)}

Albumin banyak ditemukan dalam bentuk Bovine Serum Albumin (BSA) atau Human Serum Albumin (HSA). Albumin merupakan polimer alami dengan sifat fisik dan kimianya yang unik, serta banyak digunakan didalam preparasi nanopartikel karena mampu membawa protein serbaguna untuk penargetan obat dan memperbaiki profil farmakokinetik berbasis peptida atau obat berbasis protein (Das et al. 2011). Bovine Serum Albumin (BSA) merupakan polimer yang terdiri dari asam amino yang terhubung oleh adanya ikatan peptida. BSA mampu meningkatkan biodegradabilitas dan stabilitas. Nanopartikel yang menggunakan BSA memiliki karakteristik untuk meningkatkan efek terapeutik antitumor dan drug delivery (Yang et al. 2014). Asam folat yang mengandung protein disebut sebagai reseptor folat. Reseptor folat sangat menjanjikan sebagai ligan taget untuk pengobatan kanker karena mampu memelihara fungsi sel, meningkatkan sistem kekebalan, serta memiliki penyerapan nanopartikel yang baik (Yang et al. 2014). Asam folat yang dikombinasi dengan nanopartikel cisplatin dan BSA kemudian disentrifugasi dan supernatannya disimpan untuk analisis lebih lanjut. Sampel dicuci dengan PBS, diliofilisasi dan disimpan.

Sampel NP-BSA, CP-NP-BSA dan As-CP-NP-BSA dilakukan pengukuran absorbansi dengan 
Jrnal Ilmiah Ibnu Sina, 6(1), Maret 2021, 69-78

p-ISSN: 2502-647X; e-ISSN: 2503-1902

menggunakan Spektrofotometer UV-

Vis pada panjang gelombang $358 \mathrm{~nm}$.

Dari hasil pengukuran bahwa Asam folat, Cisplatin dan Nanopartikel BSA memiliki absorbansi yang lebih tinggi dibandingkan dengan Nanopartikel BSA dan Cisplatin nanopartikel BSA. Data dapat dilihat padad tabel 1, gambar 2.

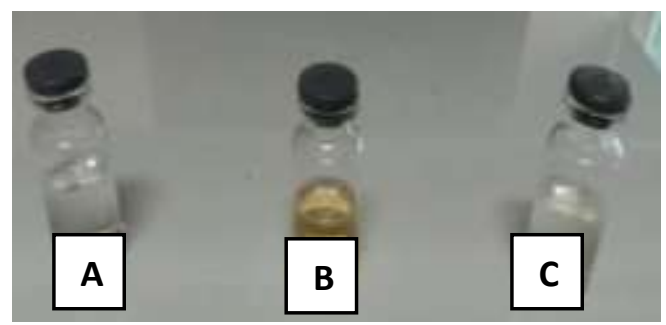

Gambar 1. Hasil Filtrat Setelah Sentrifugasi Pada Sintesis A.) NPBSA, B.) CP-NP-BSA C.) AS-CPNP-BSA

Tabel 1. Hasil pengukuran Spektrofotometer UV-Vis

\begin{tabular}{lc}
\hline \multicolumn{1}{c}{ Sampel } & Absorbansi \\
\hline NP-BSA & 0,045 \\
CP-NP-BSA & 0,844 \\
As-CP-NP-BSA & 0,86 \\
\hline
\end{tabular}

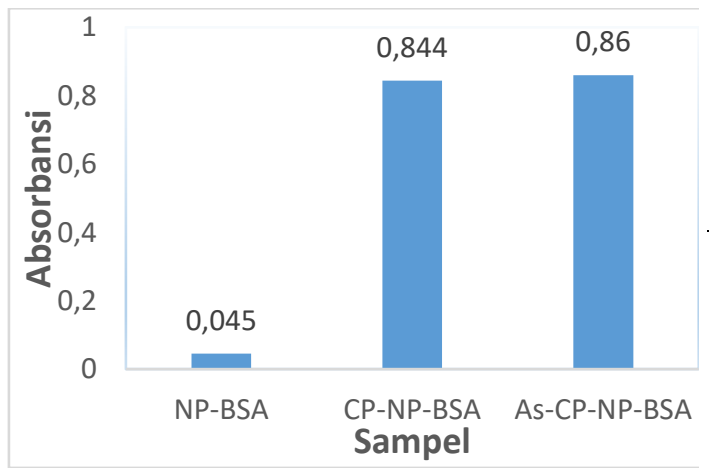

Gambar 2. Spektrofotometer UV-Vis panjang gelombang $358 \mathrm{~nm}$

\section{Uji Toksisitas Metode BSLT}

Toksisitas dapat diartikan sebagai kemampuan suatu zat untuk menimbulkan kerusakan pada organisme hidup (Millati 2016). Uji toksisitas metode BSLT dilakukan dengan menggunakan larva udang Artemia salina. Kategori toksisitas dari suatu bahan yaitu sebagai berikut (Millati 2016):

Tabel 2. Kategori toksisitas

\begin{tabular}{ll}
\multicolumn{1}{c}{ Kategori } & LC50 $(\mathbf{p p m})$ \\
\hline Sangat & $<30$ \\
Toksik & \\
Toksik & $30-1000$ \\
Tidak Toksik & $>1000$ \\
\hline
\end{tabular}

Tabel 3. Pengaruh konsentrasi terhadap kematian larva (NP-BSA)

\begin{tabular}{cccc}
\hline \multirow{2}{*}{ Konsentrasi } & $\begin{array}{c}\text { Rata- } \\
\text { Rata } \\
\text { Larva } \\
\text { Mati }\end{array}$ & $\begin{array}{c}\text { Total } \\
\text { Larva }\end{array}$ & $\begin{array}{c}\% \\
\text { Mortalitas }\end{array}$ \\
\hline 0 & 0 & 10 & 0 \\
1 & 1,3 & 10 & 13 \\
10 & 2 & 10 & 20 \\
20 & 2,3 & 10 & 23 \\
30 & 3,3 & 10 & 33 \\
40 & 3,7 & 10 & 37 \\
50 & 4,3 & 10 & 43 \\
60 & 5,3 & 10 & 53 \\
70 & 7,7 & 10 & 77 \\
80 & 10 & 10 & 100 \\
\hline
\end{tabular}

Hasil uji toksisitas menunjukkan konsentrasi yang dapat membunuh larva A.Salina dengan variasi konsentrasi 1,10,20,30,40,50,60,70,80 ppm. Jumlah larva yang diuji adalah 
Jrnal Ilmiah Ibnu Sina, 6(1), Maret 2021, 69-78

p-ISSN: 2502-647X; e-ISSN: 2503-1902

10 ekor tiap konsentrasi dilakukan pengulangan/replikasi sebanyak $3 X$. Hasil pengujian dapat dilihat pada tabel 3 .

Tabel 4. Pengaruh konsentrasi terhadap kematian larva (As-CP-NPBSA)

\begin{tabular}{cccc}
\hline Konsentrasi & $\begin{array}{c}\text { Rata- } \\
\text { Rata } \\
\text { Larva } \\
\text { Mati }\end{array}$ & $\begin{array}{c}\text { Total } \\
\text { Larva }\end{array}$ & $\begin{array}{c}\% \\
\text { Mortalitas }\end{array}$ \\
\hline 0 & 0 & 10 & 0 \\
1 & 1 & 10 & 10 \\
10 & 2 & 10 & 20 \\
20 & 3 & 10 & 30 \\
30 & 4 & 10 & 40 \\
40 & 5 & 10 & 50 \\
50 & 6 & 10 & 60 \\
60 & 7 & 10 & 70 \\
70 & 8 & 10 & 80 \\
80 & 10 & 10 & 100 \\
\hline
\end{tabular}

Berdasarkan tabel 3 dan 4 terlihat bahwa semakin tinggi konsentrasi maka semakin besar tingkat kematin larva A.Salina. Tingkat kematian dapat ditentukan secara langsung dengan membandingkan konsentrasi terendah hingga konsentrasi tertinggi. Hal ini dapat diartikan bahwa kematian larva A.Salina meningkat seiring dengan pengingkatan konsentrasi dalam sampel. Gambar larva A.Salina yang digunakan dalam uji toksisitas metode BSLT dapat dilihat dalam gambar 3 . (Runtuwene and Wewengkang 2016)

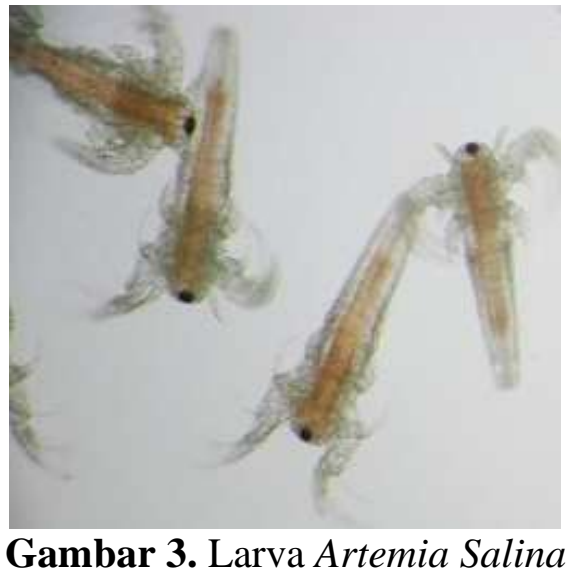

Berdasarkan tabel 3 dilakukan analisis probit menggunakan SPSS menunjukkan nilai $\mathrm{LC}_{50}$ dari NP-BSA adalah 69,23 ppm. Sedangkan berdasarkan tabel 4 hasil analisis probit menggunakan SPSS menunjukkan nilai $\mathrm{LC}_{50}$ dari As-CPNP-BSA 56,56 ppm. Menurut (Meyer et al. 1982) bahwa suatu larutan menunjukkan aktivitas toksik dalam uji toksisitas jika larutan tersebut dapat menyebabkan kematian $50 \%$ hewan uji pada konsentrasi <1000 ppm. Berdasarkan tabel 2 bahwa NP-BSA dan As- CP-NP-BSA bersifat toksik. NP-BSA memiliki nilai $\mathrm{LC}_{50}$ pada konsentrasi yang lebih tinggi $(69,23$ ppm) dibandingkan dengan As-CPNP-BSA $(56,56 \mathrm{ppm})$ hal ini berarti kombinasi asam folat \& obat cisplatin dapat menurunkan toksisitas (Maukar, Runtuwene, and Pontoh 2013). 
Jrnal Ilmiah Ibnu Sina, 6(1), Maret 2021, 69-78

p-ISSN: 2502-647X; e-ISSN: 2503-1902

\section{KESIMPULAN}

$\begin{array}{rr} & \text { Berdasarkan hasil penelitian } \\ \text { yang telah dilakukan dapat }\end{array}$ disimpulkan bahwa nanopartikel yang terdiri dari kombinasi bovine serum albumin, cisplatin dan asam folat dapat dijadikan sebagai kandidat obat antikanker. Kadar toksisitas pada NPBSA dengan nilai $\mathrm{LC}_{50}$ 69,23 ppm sedangkan kadar toksisitas As-CPNP-BSA LC L $_{50}$ 56,56 ppm. Semakin tinggi kadar konsentrasi maka semakin tinggi toksisitas yang dihasilkan.

\section{UCAPAN TERIMA KASIH}

Ucapan terima kasih diberikan kepada RISTEK-BRIN Program Kompetitif Nasional, Skema PDP yang telah memberikan dana hibah penelitian.

\section{DAFTAR PUSTAKA}

Alam, Noor et al. 2015. "Reduced Toxicological Manifestations of Cisplatin Following Encapsulation in Folate Grafted Albumin Nanoparticles." Life Sciences 142: 76-85.

Aldossary, Sara A. 2019. "Review on Pharmacology of Cisplatin: Clinical Use, Toxicity and Mechanism of Resistance of Cisplatin." Biomedical and Pharmacology Journal 11(1):
07-15.

Ambarwati, Rini. 2019. "Pembuatan Nanopartikel Albumin Menggunakan Metode Desolvasi Sebagai Alternatif Sistem Pembawa." FITOFARMAKA: Jurnal Ilmiah Farmasi 9(1): 35-39.

Bray, Freddie et al. 2018. "Global Cancer Statistics 2018: GLOBOCAN Estimates of Incidence and Mortality Worldwide for 36 Cancers in 185 Countries." CA: A Cancer Journal for Clinicians 68(6): 394-424.

Das, Saikat et al. 2011. "Nanotechnology in Oncology: Characterization and in Vitro Release Kinetics of CisplatinLoaded Albumin Nanoparticles: Implications in Anticancer Drug Delivery." Indian Journal of Pharmacology 43(4): 409-13.

Kettering, Melanie et al. 2009. "Characterization of Iron Oxide Nanoparticles Adsorbed with Cisplatin for Biomedical Applications." Physics in Medicine and Biology 54(17): 5109-21.

Maukar, Morein A, Max R.J. Runtuwene, and Julius Pontoh. 2013. "Analisis Kandungan Fitokimia Dari Uji Toksisitas Ekstrak Metanol Daun Soyogik (Sauraula Bracteosa DC) Dengan Menggunakan Metode Maserasi." Jurnal Ilmiah Sains 13(2): 98 .

Meyer, B. N. et al. 1982. "Brine Shrimp: A Convenient General Bioassay for Active Plant Constituents." Planta Medica 
Jrnal Ilmiah Ibnu Sina, 6(1), Maret 2021, 69-78

p-ISSN: 2502-647X; e-ISSN: 2503-1902

45(1): 31-34.

Millati, Nuria. 2016. “Uji Toksisitas Dengan Metode BSLT Senyawa Steroid Fraksi Petroleum Eter Mikroalga Chlorella Sp." Skripsi: 1-10.

Mutiah, Roihatul, Arief Suryadinata, and Prasasti Swara Nurani. 2018. "Uji Sitotoksik Kombinasi Cisplatin Dengan Ekstrak Etanol Benalu Aalpukat (Dendrophthoe Pentandra (L) Miq.) Pada Sel Hela." Majalah Kesehatan 5(3): 133-43.

Qi, Luyu et al. 2019. "Advances in Toxicological Research of the Anticancer Drug Cisplatin." Chemical Research in Toxicology: acs.chemrestox.9b00204.

Rahmani, Arshad H., Mohammad A. Al Zohairy, Salah M. Aly, and Masood A. Khan. 2014. "Curcumin: A Potential Candidate in Prevention of Cancer via Modulation of Molecular Pathways." BioMed Research International 2014(Figure 1).

Runtuwene, Max Revolta, and Defny Wewengkang. 2016. "Uji Aktivitas Antioksidan Dan Toksisitas Ekstrak Etanol Daun Foki Sabarati (Solanum Torvum)." Pharmacon 5(3): 94101.

Syame, Sohier M et al. 2018. "Synthesis and Characterization of Cisplatin-Loaded BSA ( Bovine Serum Albumin ) Nanoparticles as Drug Delivery System against Pancreatic Cancer Cells." 8(9): 39-48.
Usreg, Handjani Sri Usreg, Albari Husein, and Mochamad Zakki Fahmi, Ph.D. 2019. "Uji Sitotoksik Terhadap Sintesis Dan Karakterisasi Magnetik Nanopartikel $\mathrm{CuFe} 2 \mathrm{O} 4$ Yang Dilingkupi Bovine Serum Albumin (BSA)." Jurnal Kimia Riset 4(1): 7 .

Yang, Rui et al. 2014. "Preparation of Folic Acid-Conjugated, Doxorubicin-Loaded, Magnetic Bovine Serum Albumin Nanospheres and Their Antitumor Effects in Vitro and in Vivo." International journal of nanomedicine 9: 4231-43. 